\title{
Effects of Climatological and Socioeconomic Factors on Chronic Poverty
}

\author{
Michael Ndwiga Jairo (PhD) \\ University of Nairobi, Kenya
}

Doi:10.19044/esj.2019.v15n17p61～㞷L:http://dx.doi.org/10.19044/esj.2019.v15n17p61

\begin{abstract}
Poverty remains one of the key development goals for developing countries. Achieving this goals may be far-fetched given the increasing vagaries from climate change. This paper sought to estimate the effect of climate and weather variability on chronic poverty using household panel data for Kenya. Using Chamberlain random effects probit model with control function, the paper found that weather variability reduces the likelihood of a household falling into chronic poverty. Household heads with post-secondary education were less likely to fall into chronic poverty and those who earned off-farm income and had access to credit facilities had lower probability of falling into poverty as compared to those who did not. The findings suggests the need to devise policies on climate mitigation in order to cushion households from devastating effects of weather variability and to create awareness through dissemination of climate information in easy and widely accessible formats.
\end{abstract}

Keywords: Chronic Poverty, Climate and Weather Variability, Chamberlain Random Effects Probit

\section{Introduction}

Kenya faces a number of challenges one of which is high poverty rates. As outlined in the Sustainable Development Goals (SDGs), the country aims at eradicating poverty by 2030 . Achieving this target still remains a huge task for the Kenyan government given that the current rate of poverty is on the rise. For instance, more than half of the rural residents live below the poverty line (KIPPRA, 2014). The government has put deliberate measures aimed at nailing down poverty. However, some households move in and out of poverty (transient poverty) while others persistently remain poor (chronic poverty). To a large extent, policy intervention on poverty reduction has focused on transitory poverty with less emphasis on chronic poverty (Muyanga et al., 2010b; Burke and Jayne, 2010). If policies that address chronic poverty are 
not designed, millions of people will remain chronically poor (Shepherd and Brunt, 2013).

Previous studies on Kenya sought to investigate the probabilities of movement in and out of poverty (Muyanga et al., 2010b; Burke and Jayne, 2010) but considered a short period of time which may not provide a holistic picture of movement in and out of poverty. There is also limited literature that seek to examine the correlates of chronic poverty. Some studies argue that climate and weather variability my affect a farm household directly or indirectly and the effects could be enormous for chronically poor. There could also be causal relationship between chronic poverty and climate and weather variability thus requiring use of a methodology that accounts for the causal effects. For instance, Bayudan and Baje (2017) found that higher than normal rainfall contributes to increase in chronic poverty, while Camfield and Roelen (2012) argued that the timing of rains and storms increased chronic poverty in Ethiopia. Burke and Jayne (2010) found that rainfall influences chronic poverty in Kenya. With the exception of Scott (2008), other studies did not take into account climate and weather variability. Moreover, Scott (2008) did not take into account the causal relationship between chronic poverty and climate variability. Thus, there is an urgent need to understand the effect of climate and weather variability on chronic poverty in order to provide relevant information for designing respective policy interventions (Shepherd and Brunt, 2013; Duclos et al., 2006).

This paper bridges this gap by analyzing poverty dynamics using the latest household panel data for Kenya. Additionally, the paper estimates the effect of climate and weather variability on chronic poverty. Previous studies (Muyanga et al., 2010b; Burke and Jayne, 2010) ignored climate and weather variability that are critical in influencing chronic poverty particularly for Kenya where agriculture is highly dependent on weather. The paper uses Chamberlain random effects probit model with control function that does not put any restriction on the correlation between individual effects and the explanatory variables and accounts for endogeneity.

\section{Correlates of Chronic Poverty}

Various empirical studies have established different factors that cause chronic poverty. Factors that influence chronic poverty could largely be classified into three categories namely; individual characteristics, household characteristics, community, and regional level factors. On the individual characteristics, Kimsun (2012) used ordered logistic model to identify key determinants of chronic poverty in rural Cambodia. The author uses wealth index as a proxy for poverty and measured chronic poverty based on the spells approach. Higher education level of the household head was found to reduce chronic poverty while age of the household head increases the chances of 
being chronically poor. Household size, agricultural land, livestock, and social capital were also found to influence chronic poverty.

Dartanto and Nurkholis (2013) used ordered logit model to investigate determinants of chronic poverty in Indonesia. The authors used spells approach to classify households as either poor in one of the two periods, poor in both periods or never poor. The authors found that households whose heads were married were more likely to be chronically poor as compared to their unmarried counterparts while household heads with higher level of education had lower probability of being chronic poor as compared to household heads with no education. The authors found that households that lacked asset holdings were likely to be chronically poor. Nevertheless, the spells approach used by Kimsun (2012) and Dartanto and Nurkholis (2013) assumes that resources observed in a time period are not transferred across periods. However, Foster and Santos (2012) argued that households transfer their resources across periods.

In Kenya, Muyanga et al. (2010b) used censored quantile regression for the period between 1997 and 2004 to estimate determinants of chronic and transient poverty. The authors found that age of the household head increased the likelihood of a household falling into chronic poverty, while educated household heads were less likely to fall into chronic poverty. Households that had access to credit were less likely to be chronically poor. Moreover, household size, size of agricultural land, land ownership, assets, social capital, and other sources of income were found to significantly influence chronic poverty. Though Muyanga et al., (2010b) examined the effect of regional variables on chronic and transient poverty; they did not investigate the effect of climate and weather variability on chronic poverty. However, Camfield and Roelen (2012) argued that geographical conditions such as climate are major cause of chronic poverty. Muyanga et al., (2010b) focused on correlates of chronic and transient poverty for the period up to 2004, thus the study did not cover the periods when Kenyan households experienced shocks such as 2007/2008 post- election violence, global economic downturn in 2008 and erratic rainfall in 2014 (IMF, 2010). It is paramount to analyze the correlates and dynamics of poverty taking into account these shocks.

Regarding household characteristics, Imai and You (2014) used the Discrete Multi-Spell Duration Model to examine the patterns and causes of households' transitions into and out of poverty in rural China. Moreover, the authors found that households which choose farming or out-migration as a main livelihood strategy were more likely to escape from persistent poverty. Ssewanyana (2010) used spells approach to measure chronic poverty and multinomial logit model to examine the correlates of chronic and transient poverty in Northern Uganda. The author found that 40 percent of the households were chronically poor for the period 2004 to 2008 . Households 
with larger family size were more likely to fall into chronic poverty as compared to households with smaller family size while age and sex composition increased the probability of a household being chronically poor. Inadequate infrastructure such as distance to the input market and distance to trunk road increased the chances of a household falling into chronic poverty. The weakness of spells approach used by Ssewanyana (2010) is that it assumes households do not transfer their resources across periods. However, Foster and Santos (2012) argued that households transfer their resources across periods.

On the community and regional level factors, Burke and Jayne (2010) used probit model to examine the effects of spatial factors on household wealth in Kenya. The authors found that geographical isolation such as long distance to motorable road increased the chances of a household being chronically poor. Moreover, unpredictability of rainfall significantly influences chronic poverty among Kenyan households. Though the authors used rainfall as an indicator of climate they did not consider other aspects of climate such as temperature, which could influence chronic poverty. Munyanga and Musyoka (2014) used correlated random effects regression to examine the correlates of poverty in rural Kenya. The authors found that geographical conditions such as land use and time of travel from the homestead to markets had significant influence on prevalence of poverty.

Scott (2008) used qualitative data analysis technique to examine the effect of climate variability and climate change on chronic poverty in India. The authors noted that most of the chronically poor households practice rain fed agriculture which is prone to climate variability and change. Consequently, climate variability and change increases the vulnerability of the chronically poor people. This finding illustrates the importance of climate and weather variability in chronic poverty studies. As opposed to quantitative analysis, it is not possible to estimate the magnitude and direction of the effect of climate variability and change on chronic poverty using qualitative data analysis technique.

Camfield and Roelen (2012) used content analysis and qualitative comparative analysis method to understand chronic poverty in rural Ethiopia. The authors found that climate (drought, timing of rains and storms) was the major cause of households becoming or remaining poor. Other factors that influenced households falling into chronic poverty were: family illness, high food prices, own illness, death of animals, land and criminal disputes, cost of agricultural inputs, lack of labor, bad debt, and low prices of agricultural produce. Though the qualitative methods of data analysis such as life histories approach provide a list of poverty drivers and maintainers, it does not provide the magnitude of the effect of each poverty driver. 


\section{Methodology}

This paper is anchored on the livelihood approach to poverty developed by Conway (1992) and operationalized by Nkonya et al., (2008). According to Nkonya et al., (2008), a dynamic livelihood approach theory assumes that household makes investment decisions (physical capital, human capital, natural capital, social capital, financial capital, labor allocation and crop choice) so as to maximize its expected lifetime welfare as follows.

$\operatorname{Max} E_{0}\left\{\sum_{t=0}^{T} u_{t}\left(C_{t}\right)\right\}$

Where $E_{0}$ is the expectation taken with respect to uncertain factors that affect future income at the start of year $t=0, C_{t}$ denotes the value of consumption in year $\mathrm{t}, u_{t}\left(C_{t}\right)$ is a generalization of discounted utility that denotes a single period consumption utility. The value of consumption $\left(C_{t}\right)$ is a summation of gross crop income $\left(I_{c t}\right)$, net wage income $\left(I_{w t}\right)$, gross livestock income $\left(I_{l t}\right)$, off-farm income $\left(I_{n t}\right)$ and a vector of investments in assets $\left(I N V_{w t}\right)$ in year t. $p_{w t}$ is the price of marketed assets. The value of consumption is equal to total household income which is a proxy for poverty as defined in equation (2).

$$
\begin{aligned}
& T I_{i} \\
& =I_{c t}+I_{l t}+I_{w t}+I_{n t} \\
& +p_{w t} I N V_{w t} \ldots \ldots \ldots \ldots \ldots \ldots \ldots \ldots \ldots \ldots \ldots \ldots \ldots \ldots \ldots \ldots \ldots \ldots \ldots \ldots \ldots \ldots \ldots \ldots \ldots \ldots \ldots \ldots \\
& \quad \text { Where } I_{c t}, I_{w t}, I_{l t}, I_{n t} \text { and } I N V_{w t} \text { are defined as before. }
\end{aligned}
$$

From equation 2, poverty can be used as a measure of welfare which could be decomposed into both chronic and transient poverty. A household will be chronically poor if its total household income is below the poverty line for each of the survey period and it will be transiently poor if its total household income is above the poverty line in any of the survey period.

\section{Model Specification for Poverty Dynamics}

Analysis of poverty dynamics seeks to find out the probabilities associated with entries into, exits from, and re-entries into poverty, the duration of poverty and the events associated with entries into and exits from poverty (Cellini et al., 2008). The authors outlined methods that can be used to answer these questions. These methods include: tabulation or count, life tables, bivariate hazard rate, multivariate hazard rate and components-ofvariance methods. This paper uses tabulation or count method to examine households that are transiently poor for the period between 1997 and 2010 . Tabulation or count method estimates the total number of individuals entering and exiting poverty, and entry and exit rates within a specified time. Its advantage over the other methods is that it is intuitive and simple to use. Transition matrices are used to estimate the probability of entry into and exit 
from poverty at any given period. Consequently the probabilities are estimated as follows.

Probability (entry into poverty)

$$
=E P_{t} / N N P_{t-1}
$$

Probability (Exit from poverty)

$$
=L P_{t} / N P_{t-1}
$$

Where $E P_{t}$ is the number of households entering poverty in period $t$, that is, the number of non-poor households in period $t-1$ who become poor in period $t . N N P_{t-1}$ is the number of non-poor households in period $t-1 . L P_{t}$ is the number of households leaving poverty in time $t$, that is, the number of households in poverty in period $t-1$ but who escape poverty in period $t$. Finally, $N P_{t-1}$ is the number of households in poverty in period $t-1$.

\section{Model Specification for Correlates of Chronic Poverty}

World Bank (2000) defined poverty as pronounced deprivation in wellbeing. The commonly used indicators of welfare are income and consumption expenditure. Ravallion (1992) recommends the use of consumption expenditure as the best measure of welfare, since it captures consumption smoothing behavior of the household, and is less prone to measurement errors. However, this measure may not capture the consumption smoothing behavior if the household has credit constraints (Haughton and Khandker, 2009). Though income may be affected by short-term fluctuations, it is appropriate in the case where data on consumption expenditure is inadequate. This paper uses income as a measure of poverty, since available data does not contain information on consumption expenditure.

Chronic poverty can be measured using two approaches namely spells and component approach (Foster and Santos, 2012). As compared to spells approach, the component approach averages up resources over time, and it can be used to identify chronically poor people as those whose mean income overtime is below the poverty line. This paper uses component approach to identify the chronically poor. Therefore, households whose mean income is below the poverty line for the survey period are classified as chronically poor.

Based on the components approach, the probability of being chronically poor can be measured by a dummy variable. Consequently, binary outcome models can be used to analyze the effect of climate and weather variability on chronic poverty. The binary outcome models that could be used are linear probability and probit or logit models. In the case of linear probability model, it has undesirable properties, since the predicted probabilities can be less than zero or greater than one. Given the panel nature of the data, estimation of fixed effect probit is not estimable. Random effects probit and logit specification assumes strict exogeneity and zero correlation between individual effects and the explanatory variables. Fixed effects logit 
model relaxes the assumption of zero correlation between individual effects and explanatory variables, but does not consistently estimate individual effects hence marginal effects cannot be estimated (Greene, 2012). On the other hand, Mundlak fixed effects relaxes the no correlation assumption, but it would be difficult to apply it in this essay since the dependent variable, chronic poverty, does not vary within groups.

A more flexible technique that allows for correlation between random effects and explanatory variables is Chamberlain random effects probit model (Wooldridge, 2002). Chamberlain model specifies the individual effects as an explicit function of the independent variables. Chamberlain specified a latent variable model as:

$C P_{i t}^{*}=\alpha_{i}+Z_{i t}^{\prime} \beta+$

$\varepsilon_{i t}$

$\alpha_{i}=$

$$
C P_{i t}=1 \text { if } C P_{i t}^{*}>0 \text {, and } 0 \text { otherwise }
$$

$\propto+\bar{Z}_{i}^{\prime} \delta$

$+\mu_{i}$

Where $C P_{i t}^{*}$ is a latent variable, $C P_{i t}$ is a dummy variable with one indicating a chronically poor household and zero otherwise, $\mathrm{Z}$ comprises a vector of independent variables. $\beta, \alpha_{i}$ and $\varepsilon_{i t}$ denotes parameters to be estimated, unobserved individual effects and error term respectively. $\bar{Z}_{i}$ is a vector of means of the time varying variables in $Z_{i t} . \mu_{i}$ is an error term that is assumed to be uncorrelated with $\bar{Z}_{i}, \propto$ is a constant and $\delta$ is a vector of coefficients of $\bar{Z}_{i}$. i denotes household while $\mathrm{t}$ denotes time period. The probability that a household is chronically poor can be written as:

$$
\begin{array}{r}
\operatorname{Pr}\left(C P_{i t}=1 \mid Z_{i t}, \alpha_{i}\right)=\operatorname{Pr}\left(C P_{i t}=1 \mid Z_{i t}, \bar{Z}_{i}, \mu_{i}\right) \\
=\Phi\left(\propto+\bar{Z}_{i}^{\prime} \delta+Z_{i t}^{\prime} \beta+\mu_{i}\right) \ldots \ldots .
\end{array}
$$

Thus this essay estimates the following model.

$$
\begin{aligned}
& C P_{i t}^{*}= \\
& \propto+Z_{i t}^{\prime} \beta+\bar{Z}_{i}^{\prime} \delta \\
& +\mu_{i} \ldots \ldots \ldots \ldots \ldots
\end{aligned}
$$

Where $\propto, \beta, \bar{Z}_{i}, \mu_{i}, \delta$ are as defined before, $C P_{i t}^{*}$ is a latent variable measured by $C P_{i t}$ which is a dummy variable and $\mathrm{Z}$ comprises a vector of independent variables namely; household characteristics, household head characteristics, community level characteristics, and climate and weather factors.

To get the correct parameter estimates from these equations, the paper used likelihood ratio test to determine whether to use pooled estimator or panel estimator since ignoring random effects in a pooled estimation leads to inconsistent estimates. In addition, there could be reverse causality between climate and weather variability and chronic poverty. Endogeneity may arise if 
individual effects are correlated with the explanatory variables and/or due to reverse causality. This paper tested for endogeneity and addresses it by use of Chamberlain random effects probit model and control function approach (Wooldridge, 2002) and severe multicollinearity was resolved by dropping the variables that were highly correlated (Greene, 2012).

\section{Data Types and Sources}

This paper used data from Tegemeo Institute household surveys panel data. The survey collected data on household and farm characteristics, market access and data on income among others for households located in 24 out of 47 districts in Kenya. The survey collected information on Global Position System (GPS) coordinates of each household (Tegemeo Institute of Agricultural Policy and Development, 2010). The first household survey data was collected in 1997 while the latest was collected in 2010. Data on precipitation and temperature for a period of 30 years (1980 to 2010) was sourced from Kenya Meteorological Department (Kenya Meteorological Department, 2012). The climate data covered 24 districts from which Tegemeo Institute conducted its household surveys.

Based on the annual precipitation and temperature data, the paper calculated climate and weather variability at the weather station level and then interpolated the data using inverse distance weighting method in Quantum GIS software. The GPS coordinates collected by Tegemeo Institute were then used in extraction of climate and weather variability thus measuring climate and weather variability at household level. The paper sourced inflation data from the Central Bank of Kenya (Central Bank of Kenya, 2010). Linear extrapolation of Kenya National Bureau of Statistics (KNBS) national rural poverty lines for year 1997 and 2006 were used to compute the values of poverty lines for 2000, 2004, 2007 and 2010. The KNBS nominal rural poverty line for 1997 and 2006 were Kshs 1239 and 1562 per adult equivalent per month (Government of Kenya, 2007a) and the resulting linear extrapolated nominal poverty lines for 2000, 2004, 2007 and 2010 were Kshs 1347, 1490, 1598 and 1706 respectively.

\section{Results and Discussion}

The descriptive statistics show that chronic poverty is persistent in Kenya with about 34 percent of the surveyed households being chronically poor for the period between 1997 and 2010 (Table 1). This suggests that out of the 49.1 percent of the rural poor (Government of Kenya, 2007a) a large proportion are chronically poor. This is a relatively large number since Kenya aims at eradicating poverty by the year 2030 .

Over the period between 1997 and 2010, the mean age of the household heads has been rising from 51 in 1997 to 62 in 2010. Female headed 
households were 13 percent for the period between 1997 and 2004 but this proportion rose marginally by 1 percent for the period between 2007 and 2010 . The results further show that over the period between 2000 and 2010 (data on marital status in 1997 was not collected), majority of the household heads were married. Though majority of the household heads had primary education, their level of education improved with time. This finding corroborates Government of Kenya (2007a) findings that illiteracy level is declining. Household heads with up to primary education were 75.2 percent of the rural population. This suggests that majority of the less learned people are in the rural areas practicing farming.

Over the period between 1997 and 2010, the average acreage for each household has been declining. This suggests that there has been increased pressure on land due to land subdivisions. Generally, credit access and group membership has been rising over the period between 1997 and 2010 . Regarding credit access, in 1997, only 42 percent of the households could access credit as compared to about 94 percent in 2010. This could be explained by the increased financial inclusion and financial deepening across various sectors in the economy (FinAccess, 2011). Generally, distance from the household to the nearest motorable road and health centre has been declining suggesting improvement in infrastructure development. Temperature variability, a proxy for climate variability as measured by the coefficient of variation of temperature for a period of 30 years had a mean of 0.04 . The trend for weather variability in precipitation has been fluctuating over time reinforcing the fact that weather has been unpredictable.

Table 1: Summary Statistics of Variables used in the Analysis

\begin{tabular}{|c|c|c|c|c|c|c|c|c|c|c|}
\hline \multirow[b]{2}{*}{ Variable } & \multicolumn{2}{|c|}{1997} & \multicolumn{2}{|c|}{2000} & \multicolumn{2}{|c|}{2004} & \multicolumn{2}{|c|}{2007} & \multicolumn{2}{|c|}{2010} \\
\hline & M & SD & M & SD & M & SD & $\mathbf{M}$ & SD & M & SD \\
\hline \multicolumn{11}{|l|}{ Dependent variable } \\
\hline $\begin{array}{l}\text { Chronic poverty ( } 1 \text { if } \\
\text { household is } \\
\text { chronically poor, } 0 \\
\text { otherwise } \\
\text { Independent } \\
\text { Variables }\end{array}$ & 0.34 & 0.47 & 0.34 & 0.48 & 0.34 & 0.47 & 0.34 & 0.47 & 0.34 & 0.47 \\
\hline \multicolumn{11}{|l|}{$\begin{array}{l}\text { Household Head } \\
\text { Characteristics }\end{array}$} \\
\hline $\begin{array}{c}\text { Age of the household } \\
\text { head (number of } \\
\text { years) }\end{array}$ & 51.17 & 13.74 & 53.47 & 13.66 & 57.54 & 13.34 & 59.97 & 13.00 & 62.39 & 12.71 \\
\hline $\begin{array}{c}\text { Gender of the } \\
\text { household head ( } 1 \text { if } \\
\text { female, } 0 \text { otherwise })\end{array}$ & 0.13 & 0.34 & 0.13 & 0.33 & 0.13 & 0.34 & 0.14 & 0.35 & 0.14 & 0.35 \\
\hline $\begin{array}{l}\text { Household head is } \\
\text { single ( } 1 \text { if single, } 0 \\
\text { otherwise) }\end{array}$ & - & - & _ & - & 0.01 & 0.09 & 0.01 & 0.08 & 0.00 & 0.06 \\
\hline
\end{tabular}


Household head is married (1 if married, 0 otherwise)

Household head is widowed ( 1 if widowed, 0 otherwise)

Household head is divorced/separated (1 if divorced/separated, 0 otherwise)

Household head has up to primary ( 1 if primary and below, 0 otherwise)

Household head has secondary education

(1 if secondary, 0 otherwise)

Household head has

post- secondary

education ( 1 if post-

secondary, 0

otherwise)

Household

Characteristics

\begin{tabular}{|c|c|c|c|c|c|c|c|c|c|c|}
\hline $\begin{array}{c}\text { Household size } \\
\text { (number of people in } \\
\text { a household) }\end{array}$ & 7.10 & 2.65 & 8.45 & 3.28 & 5.23 & 2.40 & 7.01 & 3.18 & 6.81 & 3.26 \\
\hline $\begin{array}{c}\text { Real value of } \\
\text { agricultural assets in } \\
\text { millions (Kshs) }\end{array}$ & 0.01 & 0.03 & 0.02 & 0.06 & 0.03 & 0.15 & 0.04 & 0.17 & 0.15 & 0.40 \\
\hline Land size in acres & 6.02 & 9.75 & 5.53 & 10.05 & 6.33 & 12.66 & 6.05 & 12.11 & 5.23 & 8.98 \\
\hline $\begin{array}{l}\text { Land tenure ( } 1 \text { if } \\
\text { farmer has title deed } \\
\text { for plot of land, } 0 \\
\text { otherwise) }\end{array}$ & 0.53 & 0.50 & 0.53 & 0.50 & 0.54 & 0.50 & 0.53 & 0.50 & 0.53 & 0.50 \\
\hline $\begin{array}{l}\text { Household head } \\
\text { earned off-farm } \\
\text { income }\end{array}$ & 0.56 & 0.50 & 0.42 & 0.49 & 0.67 & 0.47 & 0.77 & 0.42 & 0.74 & 0.44 \\
\hline $\begin{array}{l}\text { Access to credit } \\
\text { facilities }\end{array}$ & 0.42 & 0.49 & 0.48 & 0.51 & 0.40 & 0.49 & 0.93 & 0.25 & 0.94 & 0.25 \\
\hline $\begin{array}{c}\text { Group membership } \\
\text { Community Level } \\
\text { Characteristics }\end{array}$ & & & 0.77 & 0.42 & 0.76 & 0.43 & 0.75 & 0.43 & 0.71 & 0.45 \\
\hline $\begin{array}{c}\text { Distance in } \\
\text { kilometers from the } \\
\text { household to } \\
\text { motorable road }(\mathrm{km})\end{array}$ & 1.12 & 1.96 & 1.25 & 1.98 & 1.06 & 1.33 & 0.52 & 0.84 & 0.46 & 0.91 \\
\hline $\begin{array}{l}\text { Distance in } \\
\text { kilometers from the } \\
\text { household to health } \\
\text { centre }(\mathrm{km}) \\
\text { Climate and Weather } \\
\text { Factors }\end{array}$ & 4.29 & 4.46 & 3.44 & 3.77 & 2.81 & 2.81 & 3.04 & 3.25 & 2.84 & 2.37 \\
\hline
\end{tabular}




\begin{tabular}{ccccccccccc}
\hline $\begin{array}{c}\text { Climate variability } \\
\text { (temperature) }\end{array}$ & 0.04 & 0.03 & 0.04 & 0.03 & 0.04 & 0.03 & 0.04 & 0.03 & 0.04 & 0.03 \\
$\begin{array}{c}\text { Weather variability } \\
\text { (precipitation) }\end{array}$ & 1.03 & 0.23 & 0.88 & 0.29 & 0.84 & 0.29 & 0.80 & 0.30 & 0.85 & 0.32 \\
\hline
\end{tabular}

$\mathrm{M}$ and SD denotes mean and standard deviation respectively

\section{Poverty Dynamics Results}

This paper used transition matrices to map changes in poverty over time. Table 2 presents transition matrix where the rows reflect poverty status and columns indicate the time period. The results show that non-poor households had a 66 percent probability of always being non-poor and a 34 percent likelihood of entering into poverty by 2000 . The poor had 31 percent probability of exiting from poverty and 69 percent probability of remaining poor by 2000. The high likelihood of poor households remaining in poverty could be explained by the prolonged economic recession witnessed in the late 1990s (Government of Kenya, 2000).

For the period between 2000 and 2004, the probability of non-poor households remaining non- poor increased by 15 percent; the probability of poor households exiting from poverty increased by 18 percent, and the probability of household that were always poor reduced by 18 percent as compared to the previous period. This improvement could be attributed to economic recovery resulting from reforms enacted by National Rainbow Coalition (NARC). Some of these reforms included poverty reduction interventions such as free primary education and constituency development fund (Government of Kenya, 2005). The increased macroeconomic stability could have reduced shocks that affect the welfare of rural households through markets (Muyanga et al., 2010a).

During the period between 2004 and 2007, non-poor households had 66 and 35 chances of remaining non-poor and entering into poor respectively. The poor had 28 and 72 percent probability of exiting from poverty and remaining poor respectively. Compared to the period between 2000 and 2004, the probability of poor households remaining poor increased by 21 percent. Among other things, this finding could be attributed to increased inflation that rose from 10.3 percent in 2005 to 14.5 percent in 2006 (Government of Kenya, 2007b). High inflation rate lowers the purchasing power and worsens the welfare of the households. Welfare of the households could have declined due to global financial crisis that disproportionately affected the poor in Kenya (ODI, 2009).

For the period between 2007 and 2010, the probability of non-poor households remaining non- poor increased by 17 percent while the probability of the poor households exiting from poverty increased by 19 percent. The probability of poor households remaining poor decreased by 19 percent as compared to the period between 2004 and 2007. Though during this period 
Kenya experienced political violence, the probability of poor households exiting from poverty could have increased due to improved weather conditions, decreased inflationary pressure coupled by stable macroeconomic environment (Government of Kenya, 2010). Overall, for the period between 1997 and 2010, the probability of a household remaining poor and always being non-poor was 44 and 80 percent respectively. Moreover, the poor had 56 percent chance of exiting from poverty reflecting the general improvement in economic growth. The average economic growth rate for the period between 1997 and 2010 was 3.45 percent (World Bank, 2012).

Table 2: Poverty Transition Matrix

\begin{tabular}{lcccccc}
\hline \multicolumn{2}{l}{ Poverty Status } & $\mathbf{1 9 9 7 - 2 0 0 0}$ & $\mathbf{2 0 0 0 - 2 0 0 4}$ & $\mathbf{2 0 0 4 - 2 0 0 7}$ & $\mathbf{2 0 0 7 - 2 0 1 0}$ & $\begin{array}{l}\mathbf{1 9 9 7} \\
\mathbf{2 0 1 0}\end{array}$ \\
\hline $\begin{array}{l}\text { Always non- } \\
\text { poor }\end{array}$ & 65.93 & 80.81 & 65.47 & 82.02 & 80.13 \\
$\begin{array}{l}\text { Non-poor } \\
\text { poor }\end{array}$ & 34.07 & 19.19 & 34.53 & 17.98 & 19.87 \\
$\begin{array}{l}\text { Poor to non- } \\
\text { poor }\end{array}$ & 30.84 & 48.31 & 27.69 & 46.18 & 55.63 \\
\begin{tabular}{l} 
Always poor \\
\hline
\end{tabular} & 69.16 & 51.69 & 72.31 & 53.82 & 44.37 \\
\hline
\end{tabular}

The paper further found that the probability of a household remaining non-poor and exiting from poverty increase with education between 1997 and 2010 (Table 3). As the level of education increases from primary to postsecondary, the probability of household remaining in poverty declined. This finding corroborates results by Ssewanyana (2010) and Muyanga et al., (2010a) that educated people have more opportunities for generating income than people with low or no education.

Table 3: Poverty Dynamics by Education Level (1997-2010)

\begin{tabular}{lccc}
\hline \multicolumn{1}{c}{ Poverty Status } & Primary and below & Secondary & Post-Secondary \\
\hline Always non-poor & 79.89 & 84.55 & 81.99 \\
Non-poor to poor & 20.11 & 15.45 & 18.01 \\
Poor to non-poor & 54.49 & 55.97 & 58.17 \\
Always poor & 45.51 & 44.03 & 41.83 \\
\hline
\end{tabular}

Poverty dynamics by gender shows that male headed households had higher probability of remaining non-poor and had less likelihood of entering poverty as compared to their female counterparts between 1997 and 2010 (Table 4). Female headed households had lower probability of exiting from poverty and had higher probability of always being poor as compared to their male counterparts. This finding suggests that female headed households are likely to have lower incomes due to limited access to ownership of productive resources (Njiro, 2003). 
Table 4: Poverty Dynamics by Gender (1997-2010)

\begin{tabular}{lcc}
\hline \multicolumn{1}{c}{ Poverty Status } & Male & Female \\
\hline \multicolumn{1}{c}{ Always non-poor } & 81.92 & 72.73 \\
Non-poor to poor & 18.08 & 27.27 \\
Poor to non-poor & 58.93 & 45.63 \\
Always poor & 41.07 & 54.37 \\
\hline
\end{tabular}

\section{Results for Effect of Climate and Weather Variability on Chronic Poverty}

The paper tested for multicollinearity and found that climate variability (precipitation) and weather variability (temperature) caused severe multicollinearity. These variables were dropped from the analysis in order to reduce multicollinearity. To choose between pooled and random effects model, this paper used likelihood ratio test where the null hypothesis was that the panel-level variance component is not important implying that the panel estimator is not different from the pooled estimator. The result for Wald test reported a rho of 284.92 that was significant at 1 percent (Table 5) implying that panel-level variance component is important. This finding suggested the use of random effects model.

Conversely, random effects probit and logit models assume no correlation between unobserved heterogeneity and covariates, while fixed effects probit model is not estimable. Fixed effects logit does not consistently estimate individual effects (Greene, 2012). Moreover, endogeneity may arise from correlation between individual effects and covariates and reverse causality between climate and weather variables and chronic poverty. This paper accounted for endogeneity by introducing group means of time varying independent variables as controls and tested for their validity based on Wald test. The Wald test result reported a value of 134.76 that is significant at 1 percent suggesting that the individual effects are correlated with the covariates. This finding suggested the use of Chamberlain model as opposed to pure random effects probit model. Chamberlain model relaxes the assumption of strict exogeneity by specifying the individual effects as an explicit function of the independent variables. However, Chamberlain model does not account for endogeneity resulting from reverse causality (Wooldridge, 2002). To account for endogeneity resulting from reverse causality, the paper introduced control function method in the Chamberlain model. Since control function method requires instruments, this paper used the lead values of the variables that were suspected to be endogenous (climate and weather variables). The validity of these instruments was tested and weather variability was found to be a good instrument.

The results for pure random effects probit and Chamberlain random effects probit model with control function are presented in Table 5. The pure random effects probit regression does not account for heterogeneity though 
the time averages shows that the effect of covariates on chronic poverty are much larger than those of Chamberlain with control function model. This paper used the latter to discuss the effects of climate and weather variability on chronic poverty in Kenya.

Among the measures of climate and weather variability considered in this paper, only weather variability in terms of precipitation significantly influence chronic poverty. The coefficient of weather variability is -0.2445 and significant at 1 percent. This implies that higher variance (less predictability) of precipitation reduces the likelihood of a household falling into chronic poverty. With increased unpredictability of precipitation, households use various adaptation strategies to cushion themselves from negative effects of weather variability and thus are unlikely to enter into chronic poverty. Benefits from adaptation to weather variability may outweigh the negative effects caused by weather variability, thereby leaving a household better off. However, this finding is contrary to apriori expectations that higher variability of precipitation hinders household's ability to raise its welfare. Camfield and Roelen (2012) argued that climate (drought, timing of rains, and storms) influences chronic poverty while Scott (2008) noted that weather variability and climate change increases the vulnerability of chronically poor people.

Table 5: Chamberlain and Pure Random Effects Probit Regression Results

\begin{tabular}{|c|c|c|c|c|}
\hline \multirow[b]{2}{*}{ Variables } & \multicolumn{2}{|c|}{$\begin{array}{c}\text { Pure random effects } \\
\text { probit }\end{array}$} & \multicolumn{2}{|c|}{$\begin{array}{c}\text { Chamberlain random } \\
\text { effects probit with control } \\
\text { function }\end{array}$} \\
\hline & Coefficient & $\begin{array}{l}\text { Average } \\
\text { partial } \\
\text { effect }\end{array}$ & Coefficient & $\begin{array}{l}\text { Average } \\
\text { partial } \\
\text { effect }\end{array}$ \\
\hline \multicolumn{5}{|l|}{ Climate and Weather Factors } \\
\hline Climate variability (temperature) & $\begin{array}{c}-42.831 * * * \\
(11.5462)\end{array}$ & $\begin{array}{l}-2.7537 \\
(0.7457)\end{array}$ & $\begin{array}{l}-13.9299 \\
(12.7536)\end{array}$ & $\begin{array}{l}-0.6998 \\
(0.6409)\end{array}$ \\
\hline Weather variability (precipitation) & $\begin{array}{c}-6.8796 * * * \\
(1.3239) \\
\end{array}$ & $\begin{array}{l}-0.4423 \\
(0.0835)\end{array}$ & $\begin{array}{c}-4.8773 * * * \\
(1.1830) \\
\end{array}$ & $\begin{array}{c}-0.2445 * * * \\
(0.0588) \\
\end{array}$ \\
\hline \multicolumn{5}{|c|}{ Household Head Characteristics } \\
\hline Age of the household head & $\begin{array}{l}0.0458 * * \\
(0.0198)\end{array}$ & $\begin{array}{c}0.0029 \\
(0.0012)\end{array}$ & $\begin{array}{c}0.0626 \\
(0.0995)\end{array}$ & $\begin{array}{c}0.0031 \\
(0.0050)\end{array}$ \\
\hline Gender of the household head & $\begin{array}{l}2.0438^{*} \\
(1.1990)\end{array}$ & $\begin{array}{c}0.1319 \\
(0.0774)\end{array}$ & $\begin{array}{r}2.2839 * * \\
(1.1235)\end{array}$ & $\begin{array}{c}0.1176 \\
(0.1598)\end{array}$ \\
\hline Household head is married & $\begin{array}{l}4.0507 * * \\
(1.9347)\end{array}$ & $\begin{array}{c}0.1801 \\
(0.1250)\end{array}$ & $\begin{array}{c}3.0997 \\
(2.0117)\end{array}$ & $\begin{array}{l}0.1346 \\
(0.1004)\end{array}$ \\
\hline Household head is widowed & $\begin{array}{c}2.8941 \\
(1.9615)\end{array}$ & $\begin{array}{c}0.1888 \\
(0.1329)\end{array}$ & $\begin{array}{c}2.3459 \\
(1.8567)\end{array}$ & $\begin{array}{c}0.1220 \\
(0.0972)\end{array}$ \\
\hline $\begin{array}{l}\text { Household head } \\
\text { divorced/separated }\end{array}$ & $\begin{array}{c}3.7332 \\
(2.6077)\end{array}$ & $\begin{array}{c}0.2454 \\
(0.1842)\end{array}$ & 3.4041 & 0.1713 \\
\hline $\begin{array}{l}\text { Household head has secondary } \\
\text { education }\end{array}$ & $-1.7675^{* *}$ & -0.1086 & -0.9185 & -0.0473 \\
\hline
\end{tabular}




\begin{tabular}{|c|c|c|c|c|}
\hline $\begin{array}{l}\text { Household head has post- } \\
\text { secondary education }\end{array}$ & $\begin{array}{c}(0.7281) \\
-4.4060 * * * \\
(1.0780) \\
\end{array}$ & $\begin{array}{l}(0.0400) \\
-0.1925 \\
(0.0307) \\
\end{array}$ & $\begin{array}{c}(0.7323) \\
-3.1297 * * \\
(1.3509) \\
\end{array}$ & $\begin{array}{c}(0.0355) \\
-0.1415^{* * *} \\
(0.0476) \\
\end{array}$ \\
\hline \multicolumn{5}{|l|}{ Household Characteristics } \\
\hline Household size & $\begin{array}{l}0.4147 * * * \\
(0.0888)\end{array}$ & $\begin{array}{c}0.0265 \\
(0.0057)\end{array}$ & $\begin{array}{l}-0.0787 \\
(0.1165)\end{array}$ & $\begin{array}{l}-0.0040 \\
(0.0059)\end{array}$ \\
\hline $\begin{array}{l}\text { Log of real value of agricultural } \\
\text { assets (Kshs) }\end{array}$ & $\begin{array}{c}-1.6486 * * * \\
(0.2165)\end{array}$ & $\begin{array}{l}-0.1054 \\
(0.0126)\end{array}$ & 0.0548 & $\begin{array}{l}0.0003 \\
(0.0155)\end{array}$ \\
\hline Land size in acres & $\begin{array}{c}-0.2202 * * * \\
(0.0463)\end{array}$ & $\begin{array}{l}-0.0142 \\
(0.0029)\end{array}$ & $\begin{array}{l}-0.0125 \\
(0.0642)\end{array}$ & $\begin{array}{l}-0.0006 \\
(0.0032)\end{array}$ \\
\hline Land tenure & $\begin{array}{l}-1.2737 * * \\
(0.5827)\end{array}$ & $\begin{array}{l}-0.0819 \\
(0.0359)\end{array}$ & $\begin{array}{c}0.1889 \\
(0.5933)\end{array}$ & $\begin{array}{c}0.0095 \\
(0.0299)\end{array}$ \\
\hline $\begin{array}{l}\text { Household head earned off-farm } \\
\text { income }\end{array}$ & $\begin{array}{c}-1.0078 * * \\
(0.4985)\end{array}$ & $\begin{array}{l}-0.0664 \\
(0.0321)\end{array}$ & $-1.1802 * *$ & $-0.06075^{* *}$ \\
\hline Access to credit facilities & $\begin{array}{l}-0.2085 \\
(0.4720)\end{array}$ & $\begin{array}{l}-0.0135 \\
(0.0303)\end{array}$ & $\begin{array}{l}-1.0310^{*} \\
(0.5531)\end{array}$ & $\begin{array}{l}-0.0528 * \\
(0.0272)\end{array}$ \\
\hline Group membership & $\begin{array}{l}-0.6053 \\
(0.5727) \\
\end{array}$ & $\begin{array}{l}-0.0397 \\
(0.0375) \\
\end{array}$ & $\begin{array}{c}0.2153 \\
(0.5934) \\
\end{array}$ & $\begin{array}{c}0.0108 \\
(0.0297) \\
\end{array}$ \\
\hline $\begin{array}{ll}\text { Community } & \text { Level } \\
\text { Characteristics } & \\
\end{array}$ & & & & \\
\hline $\begin{array}{l}\text { Distance to the nearest motorable } \\
\text { road }(\mathrm{km})\end{array}$ & $\begin{array}{l}-0.1801 \\
(0.1925)\end{array}$ & $\begin{array}{l}-0.0116 \\
(0.0123)\end{array}$ & $\begin{array}{l}-0.0456 \\
(0.2299)\end{array}$ & $\begin{array}{l}-0.0023 \\
(0.0115)\end{array}$ \\
\hline $\begin{array}{l}\text { Distance to the nearest health } \\
\text { centre }(\mathrm{km})\end{array}$ & $\begin{array}{l}0.1121 \\
(0.0791)\end{array}$ & $\begin{array}{c}0.0072 \\
(0.0051)\end{array}$ & $\begin{array}{l}0.1131 \\
(0.1257)\end{array}$ & $\begin{array}{r}0.0057 \\
(0.0063)\end{array}$ \\
\hline $\begin{array}{lll}\text { Terms to } & \text { Correct } & \text { for } \\
\text { Endogeneity } & & \\
\end{array}$ & & & & \\
\hline Mean of age of the household head & & & $\begin{array}{l}-0.0052 \\
(0.1047)\end{array}$ & $\begin{array}{c}0.0001 \\
(0.0053)\end{array}$ \\
\hline Mean of household size & & & $\begin{array}{l}1.2269 * * * \\
(0.1808)\end{array}$ & $\begin{array}{c}0.0629 * * * \\
(0.0087)\end{array}$ \\
\hline $\begin{array}{l}\text { Mean of } \log \text { of real value of } \\
\text { agricultural assets (Kshs) }\end{array}$ & & & $\begin{array}{c}-4.4347 * * * \\
(0.4629)\end{array}$ & $\begin{array}{c}-0.2237 * * * \\
(0.0212)\end{array}$ \\
\hline Mean of land size in acres & & & $\begin{array}{c}-0.2370 * * \\
(0.1065) \\
\end{array}$ & $\begin{array}{l}-0.0056 \\
(0.0053)\end{array}$ \\
\hline $\begin{array}{l}\text { Mean of distance to the nearest } \\
\text { motorable road }(\mathrm{km})\end{array}$ & & & $\begin{array}{l}0.0940 \\
(0.5375)\end{array}$ & $\begin{array}{l}0.0001 \\
(0.0270)\end{array}$ \\
\hline $\begin{array}{l}\text { Mean of distance to the nearest } \\
\text { health centre }(\mathrm{km})\end{array}$ & & & $\begin{array}{l}-0.0776 \\
(0.1424)\end{array}$ & $\begin{array}{l}-0.0012 \\
(0.0072)\end{array}$ \\
\hline $\begin{array}{l}\text { Residuals for weather variability } \\
\text { (precipitation) }\end{array}$ & & & $\begin{array}{l}3.5580 \\
(3.8781)\end{array}$ & $\begin{array}{l}0.0010 \\
(0.1948)\end{array}$ \\
\hline
\end{tabular}




\begin{tabular}{lcc}
\hline Constant & $13.3866^{* * *}$ & $28.8924 * * *$ \\
& $(2.7797)$ & $(3.4976)$ \\
Wald Chi & $209.55^{* * *}$ & $297.32^{* * *}$ \\
Wald Chi for Joint Significance & & $134.76^{* * *}$ \\
LR Test of rho=0 & $284.92^{* * *}$ & $152.54 * * *$ \\
Observations & 1,637 & 1,404 \\
Number of groups & 1,152 & 1,148 \\
\hline \multicolumn{2}{c}{ Standard errors in parentheses, $* * *, * *, *$ significant at $1 \%, 5 \%$ and $10 \%$ level }
\end{tabular}

The results for average partial effects of Chamberlain random effects probit with control function shows that post- secondary education level of the household head had a coefficient of -0.1415 that is significant at 1 percent level. The finding shows that household heads with post-secondary education had lower probability of entering into chronic poverty as compared to their counterparts who had secondary, primary or no formal education. This finding suggests that educated household heads have more opportunities for earning income which they can use to cushion their households from seasonal shocks. Household heads with primary or no formal education have less income earning opportunities, thus they are vulnerable to shocks which affect their household welfare. This finding is consistent with results of poverty dynamics which show that the more educated a household head is, the more likely it is for that household to exit from poverty. Further, this finding corroborates results by Ssewanyana (2010) and Muyanga et al., (2010b) who argued that education raises the welfare of the household in the long run.

The paper considered the effect of household size, assets, land size, land tenure, access to credit facilities, group membership and off-farm income on chronic poverty. The finding shows that off-farm income and access to credit significantly influences chronic poverty. Off-farm income included all incomes from non-farm activities and is measured as a dummy variable equals one if household earned income from non-farm activities and zero otherwise. The coefficient of off-farm income and access to credit are -0.06075 and 0.0528 respectively. This implies that household heads who earned income from non-farm activities and had access to credit facilities are less likely to enter into chronic poverty as compared to household heads who earned income from farming activities and those who didn't have access to credit facilities. Income from farming activities is prone to fluctuations due to exposure to risks such as crop or livestock diseases or decline in market prices. Thus heavy reliance on income from farming activities may expose a household to welfare loss. However, complementing such income with non-farm income reduces the risks of welfare loss and increases the chances of a household exiting from poverty. Muyanga et al., (2010b) underscored the importance of off-farm income and argued that households with diversified sources of income such as income from non-farm activities are less likely to enter into chronic poverty 
as compared to households that rely on farm income. This finding confirms Kristjanson et al., (2010) findings that Kenyan households exit poverty by diversifying their sources of income through establishment of community based enterprises such as kiosks and petty trading.

\section{Conclusion and Recommendation}

Using Chamberlain random effects probit model with control function, this paper analyzed the effect of climate and weather variability among other covariates on chronic poverty. The results showed that weather variability reduces the likelihood of a household falling into chronic poverty. This finding suggests that as precipitation become less predictable, the likelihood of households falling into chronic poverty reduces. The results further show that household heads with post-secondary education were less likely to fall into chronic poverty as compared to those with secondary, primary or no formal education. This is because educated people have more income earning/generating activities than people with secondary, primary or no education. Household heads who earned off-farm income and had access to credit facilities had lower probability of falling into poverty as compared to those who did not. This indicates the important role played by income diversification since reliance on farm income increases exposure to risks and welfare loss.

The finding of this paper reveals that weather variability is as an important determinant of chronic poverty. Thus there is need to devise policies on climate mitigation in order to cushion households from devastating effects of weather variability. There is need to create awareness through dissemination of climate information in easy and widely accessible formats. Post-secondary education lowers chances of a household falling into chronic poverty relative to secondary, primary or no formal education. This suggests the need to design policies that enhance access to post-secondary education in order to reduce chronic poverty in the long run. The findings underscored the role of off-farm income and access to credit facilities in reducing the chances of a household falling into chronic poverty. This suggests the need to design policies that promote off-farm employment opportunities in order to reduce the heavy reliance on farm income that is vulnerable to shocks. There is need to promote access to credit by removing barriers to credit access in order to reduce the likelihood of households falling into chronic poverty.

\section{References:}

1. Bayudan-Dacuycuy, C., \& Baje, L.K (2017). Chronic and Transient Poverty and Weather Variability in the Philippines: Evidence Using Components Approach. Discussion Papers DP 2017-24, Philippine Institute for Development Studies. 
2. Burke, W., \& Jayne, T. (2010). Spatial Disadvantages or Spatial Poverty Traps. Household Evidence from Kenya. Chronic Poverty Research Centre Working Paper No. 167.

3. Camfield, L., \& Roelen, K. (2012). Chronic Poverty in Rural Ethiopia through the Lens of Life Histories. Institute of Development Studies (IDS) Working Paper No 399.

4. Cellini, S., McKernan, S., \& Ratcliffe, C. (2008). The Dynamics of Poverty in the United States: A Review of Data, Methods, and Findings. Journal of Policy Analysis and Management, 27(3), 577605.

5. Central Bank of Kenya. (2010). Monthly Economic Reviews. Nairobi: Central Bank of Kenya.

6. Chambers, R. \& Conway, G. R. (1992). Sustainable Rural Livelihoods: Practical Concepts for the 21st century. IDS Discussion Paper No. 296. IDS, Brighton.

7. CPRC. (2014). The Chronic Poverty Report 2014-2015: The road to zero extreme poverty. Manchester: Chronic Poverty Research Centre.

8. Dartanto, T., \& Nurkholis. (2013). The determinants of poverty dynamics in Indonesia: evidence from panel data. Bulletin of Indonesian Economic Studies, 49(1), 61-84.

9. Duclos, J., Abdelkrim, A., \& John, G. (2006). Chronic and Transient Poverty: Measurement and Estimation with Evidence from China. CIRPEE Working Paper No. 06-11.

10. FinAccess. (2011). Financial inclusion in Kenya. Survey Results and Analysis from FinAccess 2009. Nairobi: Financial Sector Deepening (FSD) Kenya.

11. Foster, J., \& Santos, M. (2012). Measuring Chronic Poverty. Oxford Poverty \& Human Development Initiative (OPHI), Working Paper No. 52.

12. Government of Kenya (2000). Economic Survey 2000. Nairobi: Ministry of Finance and Planning.

13. Government of Kenya. (2005). Economic Survey 2005. Nairobi: Ministry of Finance and Planning.

14. Government of Kenya. (2007a). Basic Report on Well-Being in Kenya, Based on Kenya Integrated Household Budget Survey- 2005/06. Nairobi: Kenya National Bureau of Statistics, Ministry of Planning and National Development.

15. Government of Kenya. (2007b). Economic Survey 2007. Nairobi: Ministry of Finance and Planning.

16. Government of Kenya. (2010). Economic Survey 2010. Nairobi: Minister for Planning, National Development and Vision 2030. 
17. Greene, H. (2012). Econometric Analysis (7th Ed.). Upper Saddle River, N. J: Prentice Hall.

18. Haughton, J., \& Khandker, S. (2009). Handbook on Poverty and Inequality. Washington DC: World Bank.

19. Imai, K. S., \& You, J. (2014). Poverty dynamics of households in rural China. Oxford Bulletin of Economics and Statistics, 76(6), 898-923.

20. IMF. (2010). Kenya: Poverty Reduction Strategy Paper. Washington DC: International Monetary Fund (IMF).

21. Kenya Meteorological Department. (2012). Historical Precipitation and Temperature Data. Nairobi: Ministry of Environment.

22. Kimsun, T. (2012). Analysing Chronic Poverty in Rural Cambodia: Evidence from Panel Data. Cambodia's leading independent Development policy Research Institute (CDRI) Working Paper Series No. 66.

23. KIPPRA. (2014). Kenya Economic Report 2014, Navigating Global Challenges While Exploiting Opportunities for Sustainable Growth. Nairobi: Kenya Institute for Puplic Policy Research and Analysis (KIPPRA).

24. Kristjanson, P., Mango, N., Krishna, A., Radeny, M., \& Johnson, N. (2010). Understanding Poverty Dynamics in Kenya. Journal of International Development, 22, 978-996.

25. Muyanga, M., Jayne, T.S., \& Burke, W. (2010a). Pathways into and out of Poverty: A Study of Rural Household Wealth Dynamics in Kenya. Tegemeo Institute of Agricultural Policy and Development, Working Paper No. 39/2010.

26. Muyanga, M., Ayieko, M., \& Bundi, M. (2010b). Transient and Chronic Rural Household Poverty: Evidence from Kenya. PEPPMMA Working Paper No. 2007-20.

27. Muyanga, M., \& Musyoka, P. (2014). Household's Incomes and Poverty Dynamics in Rural Kenya: A Panel Data Analysis. African Economic Research Consortium, Research Paper 287.

28. Nkonya, E., Pender, J., Kaizzi, K., Kato, E., Mugarura, S., Ssali, H., \& Muwonge, J. (2008). Linkages between Land Management, Land Degradation and Poverty in Sub-Saharan Africa. The Case of Uganda. Research Report 159. Washington, D.C.: International Food Policy Research Institute.

29. ODI. (2009). The Global Financial Crisis: Poverty and Social Protection, Evidence from 10 Country Case Studies. Briefing Paper No. 51. Overseas Development Institute (ODI).

30. Okwi, P., Ndeng'e, G., Kristjanson, P., Arunga, M., Notenbaert, A., Omolo, A., Henninger, N., Benson, T., Kariuki, P., \& Owuor, J. 
(2007). Spatial determinants of poverty in rural Kenya. Proceedings of the National Academy of Sciences (USA), 104(43), 16769-16774.

31. Ravallion, M. (1992). Poverty Comparisons: A Guide to Concepts and Methods. LSMS Working Paper No. 88. Washington DC.: World Bank.

32. Scott, L. (2008). Climate Variability and Climate Change: Implications for Chronic Poverty. Chronic Poverty Research Centre Working Paper No 108. Manchester: Chronic Poverty Research Centre.

33. Shepherd, A., \& Brunt, J. (2013). Chronic Poverty: Concepts, Causes and Policy. Palgrave Macmillan.

34. Ssewanyana, S. (2010). Combating Chronic Poverty in Uganda: Towards a New Strategy. Economic Policy Research Centre (EPRC) Research Series 67 -MI02-10.

35. Tegemeo Institute of Agricultural Policy and Development. (2010). Household Survey 2010-2007 Data sets. Nairobi: Egerton University Tegemeo Institute of Agricultural Policy and Development and Michigan State University.

36. Wooldridge, J. (2002). Econometric Analysis of Cross Section and Panel Data. Cambridge, MA: MIT Press.

37. World Bank. (2000). World Development Report 2000/2001: Attacking Poverty. Washington, DC: World Bank.

38. World Bank. (2012). World Bank. (2012). World Development Indicators. Washington, DC: World Bank. 